\title{
Association of endothelial nitric oxide synthase gene polymorphisms with endometrial carcinoma: a preliminary study
}

Endometrium kanseri ile endotelyal nitrik oksit sentetaz gen polimorfizmi arasındaki ilişki: Pilot çalışma

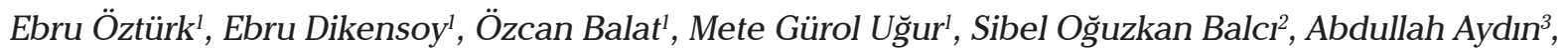 \\ Ülkü Kazancr' ${ }^{3}$ Sacide Pehlivan ${ }^{2}$ \\ 'Department of Obstetrics and Gynecology, Faculty of Medicine, Gaziantep University, Gaziantep, Turkey \\ ${ }^{2}$ Department of Medical Biology and Genetics, Faculty of Medicine, Gaziantep University, Gaziantep, Turkey \\ ${ }^{3}$ Department of Pathology, Faculty of Medicine, Gaziantep University, Gaziantep, Turkey
}

\section{Abstract}

Objective: To investigate the relationship between specific endothelial nitric oxide synthase (eNOS) gene polymorphisms and endometrial cancer (ECa). Material and Methods: The study group consisted of 89 patients histologically diagnosed with the endometrioid type of endometrial carcinoma. The control group consisted of 60 randomly selected individuals who had undergone total hysterectomy. Genomic DNA was isolated from paraffin-embedded endometrial tissues. We investigated the G894T polymorphisms (G894T) and variable number tandem repeats polymorphisms in intron 4 (VNTR intron 4) in the eNOS gene by using polymerase chain reaction (PCR) and/or restriction fragment length polymorphism (RFLP). The genotype distributions and allele frequencies of the two groups were compared.

Results: Analysis of the VNTR intron 4 polymorphisms in eNOS gene revealed that the frequency of the AA genotype was significantly higher in the control group, whereas the frequency of the BB genotype was significantly higher in the ECa group. Analysis of the G894T polymorphisms in eNOS gene revealed a significantly higher frequency of the GG genotype in the control group but a significantly higher frequency of the TT genotype in the endometrial cancer group.

Conclusion: The G894T and VNTR intron 4 polymorphisms in eNOS gene could be an intriguing susceptibility factor that modulates an individual's risk of ECa in the Turkish population.

(J Turkish-German Gynecol Assoc 2011; 12: 229-33)

Key words: eNOS gene polymorphisms, endometrial carcinoma

Received: 21 August, 2011

Accepted: 11 September, 2011

\section{Özet}

Amaç: Endometrium kanseri ile Endotelyal Nitrik Oksit Sentetaz (eNOS) gen polimorfizmi arasındaki ilişkinin ortaya konulması.

Gereç ve Yöntemler: Araştırmaya endometrioid tip endometrial karsinom tanısı almış 89 hasta çalışma grubu olarak, diğer benign sebeplerle total histerektomi uygulanmış 60 hasta kontrol grubu olarak dahil edilmiştir. Genomik DNA endometrial dokuların parafin bloklarından elde edilmiştir. Bu çalıșmada eNOS geninin G894T polimorfizmleri ve intron 4'deki değişken tekrarlayan dizi polimorfizmleri (VNTR intron 4) polimeraz zincir reaksiyonu (PCR) ve/veya enzim kesimi (RFLP) ile değerlendirilmiştir.

Bulgular: eNOS geninin VNTR intron 4 gen polimorfizmi değerlendirildiğinde AA genotip sıklığı kontrol grubunda istatistiksel olarak anlamlı ölçüde yüksek saptanırken, BB genotip sıklığı endometrial kanser grubunda yüksek olarak izlenmiştir. eNOS geninin G894T polimorfizminde ise GG genotip sıklı̆̆ kontrol grubunda yüksek izlenirken TT genotip sıklığı hasta grubunda istatistiksel olarak anlamlı ölçüde yüksek olarak saptanmıştır.

Sonuç: Türk toplumunda eNOS geninin G894T ve VNTR intron 4 polimorfizmleri endometrium kanseri için risk grubunu belirleyebilecek kişisel faktörlerden biri olabilir.

(J Turkish-German Gynecol Assoc 2011; 12: 229-33)

Anahtar kelimeler: eNOS gen polimorfizmleri, endometrium kanseri Geliş Tarihi: 21 Ağustos 2011

Kabul Tarihi: 11 Eylül 2011

\section{Introduction}

Endometrial cancer (ECa) is the most common pelvic malignancy. Each year, ECa develops in about 142,000 women worldwide and approximately 42,000 women die because of ECa (1). The majority of these tumors are of the endometrioid type that are typically hormone sensitive and have an excel- lent prognosis. Although hormonal and genetic association studies have been performed, the pathophysiology of ECa is still unclear (2-4).

Nitric oxide synthase (NOS), which has three isoforms, catalyzes the oxidation of L-arginine to nitric oxide (NO) and citrulline. Endothelial nitric oxide synthase (eNOS) is one of three isoforms of NOS that generates NO in vascular endo- 
thelium and is encoded by the eNOS gene which was localized to chromosome 7q35-36 (5). The eNOS gene have about 1,500 base pairs of upstream promoter sequence similar to other NOS and include transcription factor-binding sites that mediate regulation by estrogens, shear stress and other cofactors (6).

Under normal physiological conditions, constitutively expressed $\mathrm{NO}$ is a very important intercellular messenger molecule. However, high concentrations of metabolic products of NO have been implicated in mutagenesis and carcinogenesis (7). Potentially cytotoxic oxygen and nitrogen metabolites of NO may directly damage DNA bases, resulting in point mutations, strand breaks and interactions with sulfhydryl groups, leading to carcinogenesis. Some of these metabolites can react with secondary amines and $\mathrm{N}$-alkylamides to form nitroamines, which have been implicated in human carcinogenesis (8). Despite these negative effects on carcinogenesis, endothelial production of nitric oxide regulates blood flow and angiogenesis and reduces tumor cell adhesion to the endothelium and so positively affects tumor pathogenesis (9).

Recently, association studies on eNOS gene polymorphisms with different types of cancer including vulvar, prostate, colorectal and breast cancer have been performed (10-13).

Based on these data, the present study aimed to determine the relationship between eNOS gene polymorphisms and ECa. Although studies on Single Nucleotide Polymorphisms (SNPs) involved in DNA damage repair, steroid metabolism, carcinogen metabolism, cell-cycle control, apoptosis and steroid receptor activation pathways in ECa were performed, this is the first study in the English literature (14-18).

Although extensively different eNOS gene variants have been demonstrated, functional variation in the eNOS gene has yet to be completely characterized (19). This study has focused on two functional variants: a variant $\mathrm{G}$ to $\mathrm{T}$ conversion at nucleotide position 894 resulting in the replacement of glutamic acid with aspartic acid at codon 298 (G894T) and a variant variable number of $27 \mathrm{bp}$ tandem repeats in intron 4 (VNTR intron 4) in a Turkish population.

\section{Materials and Methods}

\section{Patients and Controls}

The study was designed as a retrospective study. Formalin-fixed (10\% neutral buffered formalin), paraffin-embedded surgical materials obtained between the years 2000 and 2010 were selected from the archives of the Department of Pathology of Gaziantep University Faculty of Medicine. The study group consisted of 89 patients histologically diagnosed with the endometrioid type of ECa. The control group consisted of 60 randomly selected individuals who had undergone total hysterectomy because of postmenopausal benign adnexal pathologies, dysfunctional uterine bleeding or myoma uteri at Gaziantep University. Hematoxylin and eosin-stained sections from each case were reviewed and representative sections for each case were selected. Genomic DNA was isolated from paraffinembedded endometrial tissues. This study was approved by the local ethics committee of Gaziantep University.

The patients were diagnosed with ECa by fractional endometrial biopsy. Thereafter, total abdominal hysterectomy, bilateral salpingoophorectomy, bilateral pelvic and para-aortic lymphadenectomy, omentectomy, and peritoneal fluid sampling were performed in all ECa patients. Histopathological diagnosis and surgical staging were established according to the International Federation of Gynecology and Obstetrics (FIGO) criteria (20). All patients were operated by the same team of surgeons and all slides were reviewed by the same pathologist.

\section{Genotyping}

We investigated the following two polymorphisms of the eNOS gene: the G894T polymorphisms; and the VNTR polymorphisms in intron 4. Genomic DNA was isolated from paraffin-embedded endometrial tissues (21). In order to analyze the G894T polymorphisms, polymerase chain reaction (PCR) was used to amplify a 206-bp fragment. The resulting fragment was digested with $\mathrm{MboI}$ restriction endonuclease (Invitrogen CA, USA) overnight at $37^{\circ} \mathrm{C}$. Digestion was resolved on a $3 \%$ agarose gel and visualized under ultraviolet light. For the analysis of the VNTR polymorphisms in intron 4 , primers were designed to amplify a 393-bp and/or 420-bp segment of the polymorphic VNTR region containing the microsatellite repeat sequence. The products were then separated on $3 \%$ agarose gel (Figures 1, 2) $(21,22)$.

\section{Statistical analysis}

Statistical Package for the Social Sciences (SPSS) for Windows (version 9.0; SPSS Inc., Chicago, IL, USA) was used for statistical analysis. Results were expressed as mean \pm standard deviation. Analysis of data regarding age was performed using the Student's t-test. A chi-square test was used to compare the two groups with

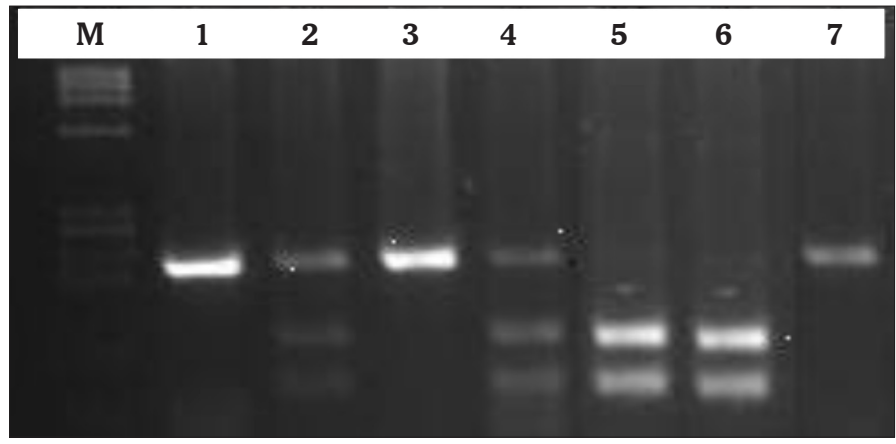

Figure 1. The G894T polymorphism. M: Marker, 1, 3, 7: The GG genotype, 2, 4: The GT genotype, 5, 6: The TT genotype

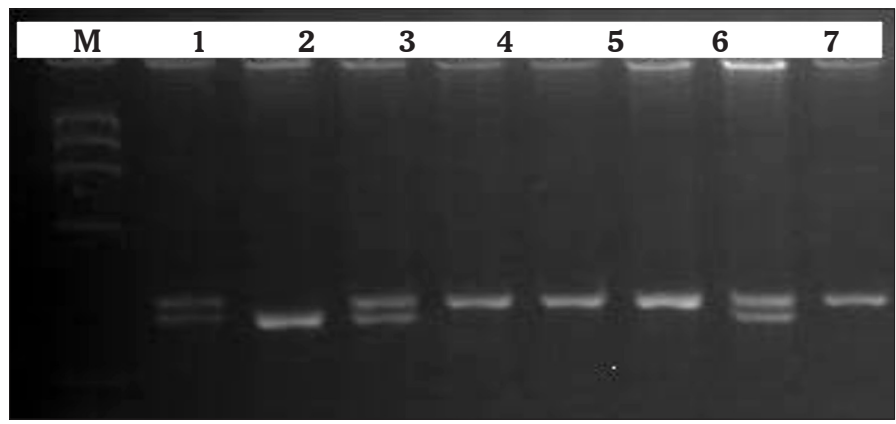

Figure 2. The variable number of tandem repeats (VNTR) polymorphism in intron 4. M: Marker, 4, 5, 6, 8: The AA genotype, 1, 3, 7: The $\mathrm{AB}$ genotype, 2: The $\mathrm{BB}$ genotype (27-kb tandem repeats) 
respect to the genotype distributions and allele frequencies. The Hardy-Weinberg equilibrium (HWE) was calculated using the Finetti programme provided as an online source (23). Analysis of variance (ANOVA) and Kruskal-Wallis test were performed to compare genotypes of VNTR intron 4 or G894T polymorphisms in eNOS gene according to age and histopathological grade. A p value of $<0.05$ was considered statistically significant.

\section{Results}

The mean age in the ECa and control groups was $62.4 \pm 1.2$ and $64 \pm 0.3$, respectively. There were no significant differences between the $\mathrm{ECa}$ and control groups with respect to age $(\mathrm{p}=0.89)$.

In the patient group; of 89 patients, 74 (83.1\%) were stage I, 7 (7.86\%) were stage II, and $8(10.0 \%)$ were stage III cancer patients. Of all patients, 39 (43.8\%) had grade 1 (well-differentiated), 30 (37.8\%) had grade 2 (moderately differentiated), and $20(22.4 \%)$ had grade 3 (poorly differentiated) tumors.

The distribution of genotypes and allele frequencies are shown in Table 1 and Table 2. Regarding the VNTR intron 4 polymorphisms, while there was no deviation from HWE in control and patient groups, a significant difference existed between the two groups with respect to the genotype distribution. Comparison of the two groups revealed that the frequency of the AA genotype was significantly higher in the control group, while the frequency of the BB genotype was significantly higher in the ECa group $(\mathrm{p}=0.015$ and $\mathrm{p}=0.015$, respectively).
Regarding the G894T polymorphisms, there was a significant difference between the two groups with respect to the genotype distribution. There was no deviation from HWE in patient and control groups. Comparison of the two groups revealed a higher frequency of the GG genotype in the control group, whereas there was a significantly higher frequency of the TT genotype in the ECa group ( $p=0.003$ and $p=0.003$, respectively).

No correlation was observed between patient age or histopatholgical grade and genotypes for the VNTR intron 4 polymorphisms $(p=0.991, p=0.719)$ and for the G894T polymorphisms $(\mathrm{p}=0.560, \mathrm{p}=0.178)$.

\section{Discussion}

Although ECa is the most common gynecologic cancer worldwide and numerous studies have been performed on risk factors or prognostic factors, the underlying carcinogenic mechanisms remain unknown $(24,25)$. Unopposed and prolonged estrogen stimulation, including stimulation by nulliparity, late menopause, and obesity, has been identified as a risk factor for the development of ECa. Estrogen acts in two different ways in the carcinogenesis of $\mathrm{ECa}$; as a hormone that stimulates cell proliferation and as a procarcinogen that induces genetic damage by the action of free radicals. Cellular and molecular vascular studies demonstrated the estrogeninduced rapid, membrane-initiated activation of numerous signal transduction cascades (26). These effects include estrogen-stimulated, rapid activation of eNOS, resulting in

Table 1. Comparison of eNOS/VNTR intron 4 and eNOS/G894T gene polymorphisms genotype frequencies between patients with endometrial cancer and healthy controls

\begin{tabular}{|c|c|c|c|c|c|c|}
\hline & \multirow[t]{2}{*}{ Genotypes } & \multicolumn{2}{|c|}{ Endometrial cancer } & \multicolumn{2}{|c|}{ Control } & \multirow[t]{2}{*}{$\mathbf{p}$} \\
\hline & & $\mathbf{n}^{\mathrm{a}}$ & (\%) & $\mathbf{n}^{\mathrm{b}}$ & $(\%)$ & \\
\hline \multirow{3}{*}{ eNOS/ VNTR intron 4} & AA & 48 & (53.9) & 43 & (71.7) & 0.015 \\
\hline & $\mathrm{AB}$ & 31 & (34.8) & 16 & (26.7) & 0.101 \\
\hline & BB & 10 & (11.3) & 1 & $(1.6)$ & 0.015 \\
\hline HWE $p$ & & 0.162 & & 0.723 & & \\
\hline \multirow[t]{3}{*}{ eNOS/G894T } & GG & 47 & $(52.8)$ & 42 & $(70)$ & 0.003 \\
\hline & GT & 31 & (34.8) & 18 & $(30)$ & 0.235 \\
\hline & TT & 11 & (12.4) & 0 & (0) & 0.003 \\
\hline HWE p & & 0.114 & & $(0.171)$ & & \\
\hline
\end{tabular}

Table 2. Comparison of eNOS/VNTR intron 4 and eNOS/G894T gene polymorphisms allele frequencies between patients with endometrial cancer and healthy controls

\begin{tabular}{|l|c|c|c|c|c|c|}
\hline \multirow{2}{*}{ Alleles } & \multicolumn{2}{|c|}{ Endometrial cancer } & \multicolumn{2}{|c|}{ Control } & \multirow{2}{*}{$\mathbf{p}$} \\
\cline { 3 - 6 } & & $\mathbf{n}^{\mathrm{a}}$ & $\mathbf{( \% )}$ & $\mathbf{n}^{\mathrm{b}}$ & $\mathbf{( \% )}$ & \\
\hline \multirow{2}{*}{$\mathrm{eNOS} /$ VNTR intron 4 } & $\mathrm{A}$ & 127 & $(71.3)$ & 102 & $(85)$ & 0.006 \\
\cline { 2 - 6 } & $\mathrm{B}$ & 51 & $(28.7)$ & 18 & $(15)$ & \\
\hline \multirow{2}{*}{$\mathrm{eNOS/G894T}$} & $\mathrm{G}$ & 125 & $(70.2)$ & 102 & $(85)$ & 0.003 \\
\cline { 2 - 6 } & $\mathrm{T}$ & 53 & $(29.8)$ & 18 & $(15)$ & \\
\hline $\mathrm{n}^{\mathrm{a}}=178, \mathrm{n}^{\mathrm{b}}=120, *: \mathrm{OR}(95 \% \mathrm{Cl})$ was adjusted by age, ${ }^{8}$ Fisher's Exact Test
\end{tabular}


production of NO which has implications in carcinogenesis, tumour progression, invasion, angiogenesis and modulation of therapeutic responses $(27,28)$.

In the literature, several SNPs of the eNOS gene have been reported in various cancers with increased risk of developing malignancy $(11,29)$ and prognosis after developing malignancy $(30,31)$; however, there is no study in the literature investigating the relationship of SNPs of the eNOS gene with ECa. Recently, Hao et al. performed a meta-analysis about G894T polymorphisms of eNOS gene in breast cancer which has similar risk factors such as nulliparity, late menopause, and obesity to ECa (11). They concluded that there was a significant association between the eNOS polymorphism and the risk of breast cancer. The result of our study on G894T polymorphisms of eNOS gene in ECa suggest that, while the homozygote $\mathrm{T}$ variant of G894T polymorphisms in eNOS could be a predisposing factor for ECa, the homozygote $\mathrm{G}$ variant could be a protective factor for ECa in Turkish population.

In the literature, only a few case-control studies have been performed to evaluate the role of intron 4 polymorphisms in cancer. Although VNTR intron 4/eNOS variant is less likely to be functional, recently Yeh et al. demonstrated the association between VNTR intron 4/eNOS polymorphisms and early-onset colorectal cancer (13). In this study, we observed the association between VNTR intron 4/eNOS polymorphisms and ECa.

To the best of our knowledge, this is the first report of a relationship between eNOS gene polymorphisms and ECa.

In conclusion, Glu298Asp and VNTR intron 4 polymorphisms in the eNOS gene could be an intriguing factor that modulates an individual's risk of ECa in Turkish population. However, further studies with a large number of patients to clarify the association between eNOS gene polymorphisms and risk of developing $\mathrm{ECa}$ and to evaluate the relationship between prognosis in $\mathrm{ECa}$ and eNOS gene polymorphisms are needed.

\section{Conflict of interest}

No conflict of interest was declared by the authors.

\section{References}

1. Amant F, Moerman P, Neven P, Timmerman D, Van Limbergen E, Vergote I. Endometrial cancer. Lancet 2005; 366: 491-505. [CrossRef]

2. Meydanlı M, Karadag N, Kose F, Tulunay G, Ozfuttu A. Body Mass Index is Associated with Immunohistochemical Nuclear Phosphatase and Tensin Homolog Deleted on Chromosome 10 (PTEN) Expression in Stage IB-IC Endometrioid Endometrial Carcinoma. J Turkish-German Gynecol Assoc 2007; 8: 408-14.

3. Ozler A, Kuscu NK, Temiz P, Kandiloglu AR, Koyuncu FM. Leptin expression in proliferative, secretory and hyperplastic endometrial tissues. J Turkish-German Gynecol Assoc 2011; 12: 157-61. [CrossRef]

4. Ozturk HB, Vural B, Caliskan E, Solakoglu S. Effect of GnRH analogues and octreotide treatment on apoptosis and the cell proliferation of endometrium adenocarcinoma cell lines. J TurkishGerman Gynecol Assoc 2010; 11: 131-6. [CrossRef]

5. Marsden PA, Heng HH, Scherer SW, Stewart RJ, Hall AV, Shi XM, et al. Structure and chromosomal localization of the human constitutive endothelial nitric oxide synthase gene. J Biol Chem 1993; 268: 17478-88.
6. Hingorani AD. Polymorphisms in endothelial nitric oxide synthase and atherogenesis: John French Lecture 2000. Atherosclerosis 2001; 154: 521-7. [CrossRef]

7. Mirvish SS. Role of N-nitroso compounds (NOC) and N-nitrosation in etiology of gastric, esophageal, nasopharyngeal and bladder cancer and contribution to cancer of known exposures to NOC. Cancer Lett 1995; 93: 17-48. [CrossRef]

8. Bentz BG, Barnes MN, Haines GK, Lurain JR, Hanson DG, Radosevich JA. Cytoplasmic localization of endothelial constitutive nitric oxide synthase in endometrial carcinomas. Tumour Biol 1997; 18: 290-300. [CrossRef]

9. Charles IG, Scorer CA, Moro MA, Fernàndez C, Chubb A, Dawson $\mathrm{J}$, et al. Expression of human nitric oxide synthase isozymes. Methods Enzymol 1996; 268: 449-60. [CrossRef]

10. Riener EK, Hefler LA, Grimm C, Galid A, Zeillinger R, Tong-Cacsire $\mathrm{D}$, et al. Polymorphisms of the endothelial nitric oxide synthase gene in women with vulvar cancer. Gynecol Oncol 2004; 93: 686-90. [CrossRef]

11. Hao Y, Montiel R, Huang Y. Endothelial nitric oxide synthase (eNOS) $894 \mathrm{G}>\mathrm{T}$ polymorphism is associated with breast cancer risk: a meta-analysis. Breast Cancer Res Treat 2010; 124: 809-13. [CrossRef]

12. Lee KM, Kang D, Park SK, Berndt SI, Reding D, Chatterjee N, et al. Nitric oxide synthase gene polymorphisms and prostate cancer risk. Carcinogenesis 2009; 30: 621-5. [CrossRef]

13. Yeh CC, Santella RM, Hsieh LL, Sung FC, Tang R. An intron 4 VNTR polymorphism of the endothelial nitric oxide synthase gene is associated with early-onset colorectal cancer. Int J Cancer 2009; 124: 1565-71. [CrossRef]

14. Meyer LA, Westin SN, Lu KH, Milam MR. Genetic polymorphisms and endometrial cancer risk. Expert Rev Anticancer Ther 2008; 8: 1159-67. [CrossRef]

15. Esinler I, Aktas D, Alikasifoglu M, Tuncbilek E, Ayhan A. CYP1A1 gene polymorphism and risk of endometrial hyperplasia and endometrial carcinoma. Int J Gynecol Cancer 2006; 16: 1407-11. [CrossRef]

16. Junqueira MG, da Silva ID, Nogueira-de-Souza NC, Carvalho CV, Leite DB, Gomes MT, et al. Progesterone receptor (PROGINS) polymorphism and the risk of endometrial cancer development. Int $\mathrm{J}$ Gynecol Cancer 2007; 17: 229-32. [CrossRef]

17. Xu L, Hu Y, Chen B, Tang W, Han X, Yu H, et al. Mitochondrial polymorphisms as risk factors for endometrial cancer in southwest China. Int J Gynecol Cancer 2006; 16: 1661-7. [CrossRef]

18. Saffari B, Bernstein L, Hong DC, Sullivan-Halley J, Runnebaum IB, Grill HJ, et al. Association of p53 mutations and a codon 72 single nucleotide polymorphism with lower overall survival and responsiveness to adjuvant radiotherapy in endometrioid endometrial carcinomas. Int J Gynecol Cancer 2005; 15: 952-63. [CrossRef]

19. Casas JP, Cavalleri GL, Bautista LE, Smeeth L, Humphries SE, Hingorani AD. Endothelial nitric oxide synthase gene polymorphisms and cardiovascular disease: a HuGE review. Am J Epidemiol 2006; 164: 921-35. [CrossRef]

20. Mikuta JJ. International Federation of Gynecologic and Obstetrics staging of endometrial cancer. Cancer 1988; 71: 1460-3. [CrossRef]

21. Erciyas K, Pehlivan S, Sever T, Igci M, Pehlivan M, Arslan A, et al. Endothelial nitric oxide synthase gene polymorphisms associated with periodontal diseases in Turkish adults. African J Biotechnology 2010; 9: 3042-7.

22. Erciyas K, Pehlivan S, Sever T, et al. Endothelial nitric oxide synthase gene polymorphisms associated with periodontal diseases in Turkish adults. African J Biotechnology 2010; 9: 3042-7.

23. Mendell NR, Simon GA. A general expression for the variancecovariance matrix of estimates of gene frequency: the effects of departures from Hardy-Weinberg equilibrium. Ann Hum Genet 1984; 48: 283-6. [CrossRef]

24. Turan AT, Dundar B, Gundogdu B, Boztosun A, Özgül N, Boran N, et al. The effect of cell type on surgico-pathologic risk factors in 
endometrial cancer. J Turkish-German Gynecol Assoc 2011; 12: 9-14. [CrossRef]

25. Turan T, Ortac F, Güngör M, Heper A, Ensari A. Angiogenesis is not a prognostic marker in endometrial carcinoma. J Turkish-German Gynecol Assoc 2000; 1: 13-6.

26. Emons G, Fleckenstein G, Hinney B, Huschmand A, Heyl W. Hormonal interactions in endometrial cancer. Endocr Relat Cancer 2000; 7: 227-42. [CrossRef]

27. Duckles SP, Miller VM. Hormonal modulation of endothelial NO production. Pflugers Arch 2010; 459: 841-51. [CrossRef]

28. Singh S, Gupta AK. Nitric oxide: role in tumour biology and iNOS/ NO-based anticancer therapies. Cancer Chemother Pharmacol 2011; 67: 1211-24. [CrossRef]
29. Cheon KT, Choi KH, Lee HB, Park SK, Rhee YK, Lee YC. Gene polymorphisms of endothelial nitric oxide synthase and angiotensinconverting enzyme in patients with lung cancer. Lung 2000; 178: 351-60. [CrossRef]

30. Ghilardi G, Biondi ML, Cecchini F, DeMonti M, Guagnellini E, Scorza R. Vascular invasion in human breast cancer is correlated to T-786C polymorphism of NOS3 gene. Nitric Oxide 2003; 9: 118-22. [CrossRef]

31. Mozet C, Marin DG, Bertolini J, Tannapfel A, Wichmann G, Dietz A. Nitric oxide synthase (NOS2/3) expression in head and neck squamous cell carcinomas in correlation with clinical patterns. Onkologie 2009; 32: 655-60.[CrossRef] 